\title{
Work-Life Balance Reality among Czech Managers: Staying Halfway
}

\author{
Martina Rašticová and Štěpán Konečný \\ Department of Law and Humanity Sciences, Faculty of Business and Economics \\ MENDEL UNIVERSITY IN BRNO Zemědělská, Czech Republic \\ Department of Management, Faculty Of Business And Management \\ BRNO UNIVERSITY OF TECHNOLOGY \\ Kolejní, Brno, Czech Republic
}

Correspondence should be addressed to: Martina Rašticová; martina.rasticova@mendelu.cz

Received date: 9 October 2015; Accepted date: 24 December 2015; Published date: 15 March 2016

Copyright (C) 2016. Martina Rašticová and Štěpán Konečný . Distributed under Creative Commons CC-BY 4.0

\begin{abstract}
While developed companies have for a long time, due to efficiency and competitiveness, facilitated better reconciliation of work and family life of their employees; in reality in the Czech Republic these business solutions are still not at the level achieved in other countries. In our research, we decided to analyze the options of managers and workers in senior positions in five professional areas to achieve work life balance depending on their age and gender. An inquiry was carried out using a sample of 148 respondents asking questions concerning the options offered by the employer and those preferred by the respondents for work-life balance. The research of the options for work-life balance offered by the employer reflects particular situations in a sample of Czech-based companies and organizations. The results corroborated the rigidity of options offered by the employer to senior employees. According to the results of the research on the work-life-balance options as preferred by the employees, the majority would welcome more possibilities for handling with their work time: part-time work, flexible working hours and working from home. The different preferences of male and female employees and the differences given by the professions are discussed in detail. The results thus suggest that despite proclamations about the benefits of work - life balance for companies, the typical situation in the Czech Republic is slightly more improvement in the work-life balance, while the majority of staff is still waiting for substantial changes concerning especially time possibilities.
\end{abstract}

Keywords: Diversity management; gender management; work-life balance

\section{Introduction}

Efficient management and leadership of diversified teams is the latest challenge facing human resources departments in all organizations striving for competitiveness. The theory of economic growth formulated by R. Florida in 2004 (also dubbed 3T theory) states that individual and organizational tolerance is instrumental in building diversified teams which then serve as hothouses for talent guaranteeing technological progress. Work-life balance is one of the concepts that can provide

Cite this Article as: Martina Rašticová and Štěpán Konečný (2016), “ Work-Life Balance Reality among Czech Managers: Staying Halfway", Journal of Electronic Banking Systems, Vol. 2016(2016),

Article ID 744425, DOI: 10.5171/2016. 744425 
employees with more incentives, thereby making their work more efficient.

Workplace diversity refers to the variety of differences between people in an organization such as their nationality, ethnicity, sex, gender, education, etc. (Greenberg, 2004). Katherine Klein, however, points out that diversity cannot be reduced to mere demographic terms such as gender, race, and age. She emphasizes that it also involves various attitudes, skills, knowledge, and power, which often play a crucial role in the dynamics of a diversified team (Harrison, Klein, 2007).

The management of organizational diversity aims to use the capacity and potential of a diversified work team. Generally, diversity may be described at individual, group, and organizational levels (Cox, 1993; see also Groeschke, 2011).

\section{Diversity, age, and gender management}

Keil defines diversity management as an active, deliberate building of a strategic, value-oriented communication and management process orientated towards the future, consisting in the acceptance and use of certain differences and similarities as the organization's potential drivers. In an organization this process adds value (Keil et al., 2007, p. 7). Diversity management can take on a number of forms, with the most frequent form in practice being gender and age management.

The challenge of age management is to find out how quickly a work team ages, what is its structure, and what are its future tasks and needs (Rašticová, Kolářová, 2013; Putnová, 2013). This, then, entails the choice of strategies and tools by human resources departments to match the changing conditions of an ageing work team. Generational differences are taken into consideration as diversity issues that an organization must understand and accept and as a matter that needs to be attended to by the present and future managers (Arsenault, 2004, p. 124). Over the last decade, there have been numerous studies done on older workers, while research on multi-generation working environment (generation $\mathrm{X}$ and generation $Y$ ) is still at an early stage. However, it is mainly long-term research of multigeneration teams and the mutual influence between generations that can shed light on whether generation patterns are the consequence of age, generation, or stage of life.

Gender management has been discussed for a number of years. The Commonwealth Secretariat (1999) defines gender management as a network of structures, mechanisms, and processes that are interleaved with the existing organizational system designed to implement, plan for, monitor, and evaluate the inclusion of gender issues in all aspects of work organization.

Latent mechanisms that often prevent handicapped groups in the workplace (in the Czech environment, these are mostly women and people aged 50+) from career advancement include the glass ceiling; multiple glass ceiling; glass cliff; mini-me syndrome, etc. (see Bartošová, 2008; Rašticová, 2007; Mahalingam, Leu, 2005; Riglová, Skálová, 2008; Kř́ížková, 2002, 2003 and others.).

According to research done by eFinancialCareers.de (2011), women work in less than $10 \%$ of senior management positions in German banking and financial services. Moreover, $92 \%$ of women in this sector believe that career opportunities for women are inferior to those for men. Among the most frequent barriers that women striving for management positions have to face are the "gents' club" in top management, issues related to parental leave, child-care, and lower salaries.

Forty-nine percent of men see the career opportunities for women as worse. Almost half of the men ( $45 \%$ ) then agree that if women want to advance to management positions they must overcome more obstacles. More than three quarters (78\%) of men still believe that the number of women in senior positions will increase in 
the coming five years. Only $56 \%$ of women believe this to be true.

\section{Work life balance}

These are the concrete options offered to achieve work life balance: part-time work, company kindergarten, flexible working hours, management of maternal and parental leave, work from home, shared jobs, compressed working week, leisure benefits (Králíková, 2010; see also Vohlídalová, 2007).

New directions and approaches emerge in career building according to Fischlová and Gazdová (2006). Despite career building being slower and more difficult for women for the above reasons, the importance of career as a value of life and the ways a career is integrated into personal life change. After graduation or before it, women of older generations had already set up a family, and when the children grew up, started to build their careers. Younger generations of women begin with career building right after graduation delaying, or even completely abandoning, family and motherhood. A career has become an important priority in life for the modern young woman. While work-life balance is now much easier to reach, thanks to modern convenience and household appliances, it is often complicated by the attitudes of many employers who believe that balancing personal life with career is a problem employees or their families must deal with. (ibidem).

An interesting project is the initiative of Gender Studies (2010) to give the best employers and companies introducing equal opportunities and work life balance options a Company of the Year: Equal Opportunities award.

\section{Research objective}

Carrying on the research on the leadership of diversified teams in the workplace while focusing on the work-life balance of employees (see Rafnsdóttir, Heijstra, 2011, Bosničová, 2010, Králíková, 2010 and others.) and taking into account the specific situation of work teams in a globalizing Czech society, the research objective has been formulated as follows.

The research aims to analyse the work life balance options offered to female and male managers and senior executives in five sectors depending on their age and gender (see also Rašticová, 2012). The sectors investigated include:

- financial and tax consulting and auditing,

- information and communication technology,

- industry,

- healthcare,

- education.

The data were collected from December 2010 to April 2011. With the agreement of company representatives, e-questionnaires were sent to managers to be filled in and submitted. The total number of questionnaires sent to managers was 232 from a total of 22 companies and organizations. Relatively high percentages (68.3) of the questionnaires were returned. The companies and organizations wished to stay anonymous, however, all of them have been located in the Czech Republic for a minimum of four years with employee numbers ranging between 70 and 800 . The respondents were only required to enter data concerning the sector in which they worked.

\section{Sample Description}

A total of 148 respondents, $52 \%$ men and $48 \%$ women, were involved in the research. The age was less evenly distributed over the sample (see Fig 1). The most frequent age group was that of 30 to 39 years $(39.3 \%)$. The percentages of other age brackets were between 10 and 22.1. The research sample consisted mostly of childless respondents or respondents with children older than 20 years $(64 \%$ of respondents). About one quarter (24.7\%) said that their child/children were aged 8 years or younger. The length of employment of the respondents was mostly 1 to 5 years (38.5\%), almost one quarter $(23 \%)$ had worked with the 
present employer from 6 to 10 years. Thus, a major part of the research sample consisted of respondents employed by the present employer for 1 to 10 years (a total of $61.5 \%$ ). Most of them said that they worked full time (77.3\%) and about one fifth was working part time $(22.7 \%)$. The data indicated that more than half of the respondents $(56.1 \%)$ worked as managers or heads of small departments (with five or less persons), about one third (27.7\%) were in the medium-manager positions (heading departments of five to thirty persons), the remaining respondents being managers in executive or strategic positions. In terms of the sectors in which the respondents work, the sample is distributed rather evenly. The bulk of the respondents work in finance and tax consulting with major consulting and auditing companies (26.4\%), next in industrial plants $(25 \%)$, in the ICT sector $(18,9 \%)$, managers and senior executives in education formed $16.2 \%$ of the sample, and managers of health care facilities were represented by $13.5 \%$.

\section{Results}

The sample data were analysed by the SPSS program using statistical methods including $t$ - tests, $\chi^{2}$ - tests, correlation analysis, and others. The research outcomes are discussed in detail at the end of the chapter. For the purposes of statistical analysis, the below demographic categories (except the sex and work sector) were re-coded as follows:

- the age structure category was divided into two subgroups respondents aged below 40 years $(50.3 \%)$ and above 40 years (49.7\%);

- the family status category was divided into two subgroups respondents living in a family or common household (64.9\%) and other respondents (single, divorced, widows and widowers, etc. $-35.1 \%$ );

- the number of children category was divided into two subgroups respondents with no children or with children aged $20+(64 \%)$ and those with one or more children aged below 20 years (36\%);

- the length of employment category was divided into three subgroups respondents having worked with the present employer for less than 5 years $(42.6 \%), 6$ to 10 years (23\%), $11+$ years $(34.5 \%)$;

- the part-time percentage category was divided into two subgroups respondents working full time $(77.3 \%)$ and those working part time $(22.7 \%)$;

- the managerial position category was divided into two subgroups respondents working as managers or heads of small departments (with five or less persons - 56.1\%), respondents working as mid or top managers (in departments of five or more persons $-43.9 \%$ ).

Work life balance options that a company striving for competitiveness should offer

All the work life balance options were supported by more than a half of the respondents in the following order (see Fig $1)$ : part time work supported by $66.5 \%$, flexible working hours by $64.7 \%$, home office by $61.2 \%$, and company kindergarten by $54.7 \%$ of the respondents. 


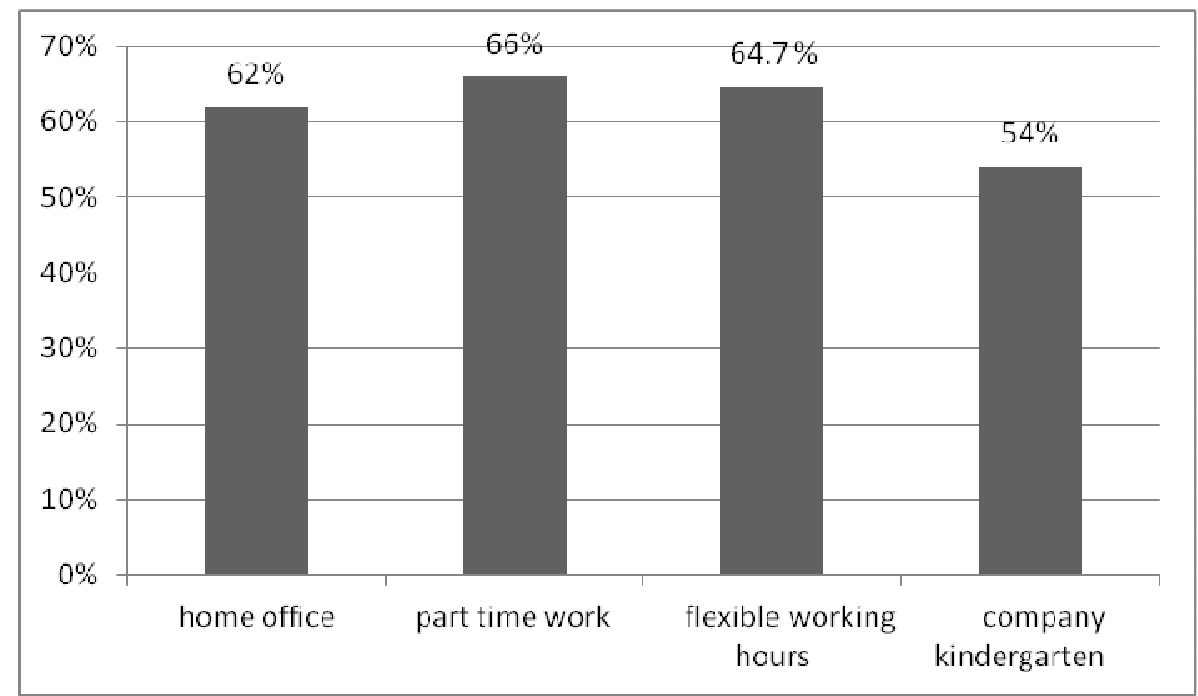

Source: author's own analysis

$N=148$

Figure 11: Work life balance preferences at companies striving for competitiveness by keeping good employees.

Next, by statistical methods, we determined the relationship between the work life balance options (see above) and all the demographic categories considered (sex, age, family status, number of children, length of employment, part-time percentage, position in management, and work sector). Listed below are the major relationships and those proved to be statistically significant. An analysis of the responses of men and women concerning their preferences unequivocally confirms that women prefer all four options offered more often than men (see Fig 2). The differences between men and women are statistically significant in the cases of flexible working hours $\left(\chi^{2}\right.$ (df 1$)=25.084$, $\mathrm{p}=0.0001)$ and company kindergarten $\left(\chi^{2}\right.$ (df 1)=35.962, p=0.0001). Here, an overwhelming majority of women believe that it is the options of flexible working hours and company kindergarten that may help a company striving for competitiveness win and keep good employees. 


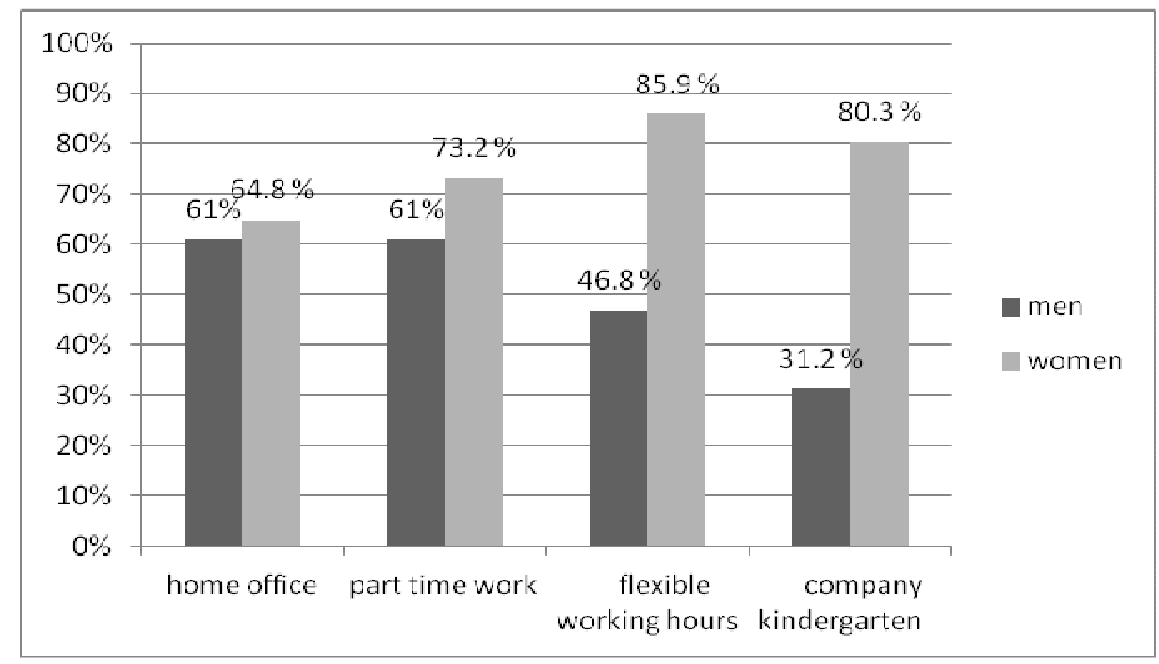

Source: author's own analysis $\mathrm{N}=148$

Figure 2: Differences between men's and women's positive responses to the home office, part-time work, flexible working hours, and company kindergarten options.

According to an analysis of the relationships between respondents with no children and those having a child or children depending on their sex, women with one or more children believe more
(82.8\%) than other respondents (men and childless women) that part-time work may improve the company's competitiveness by keeping good employees (see Fig 3).

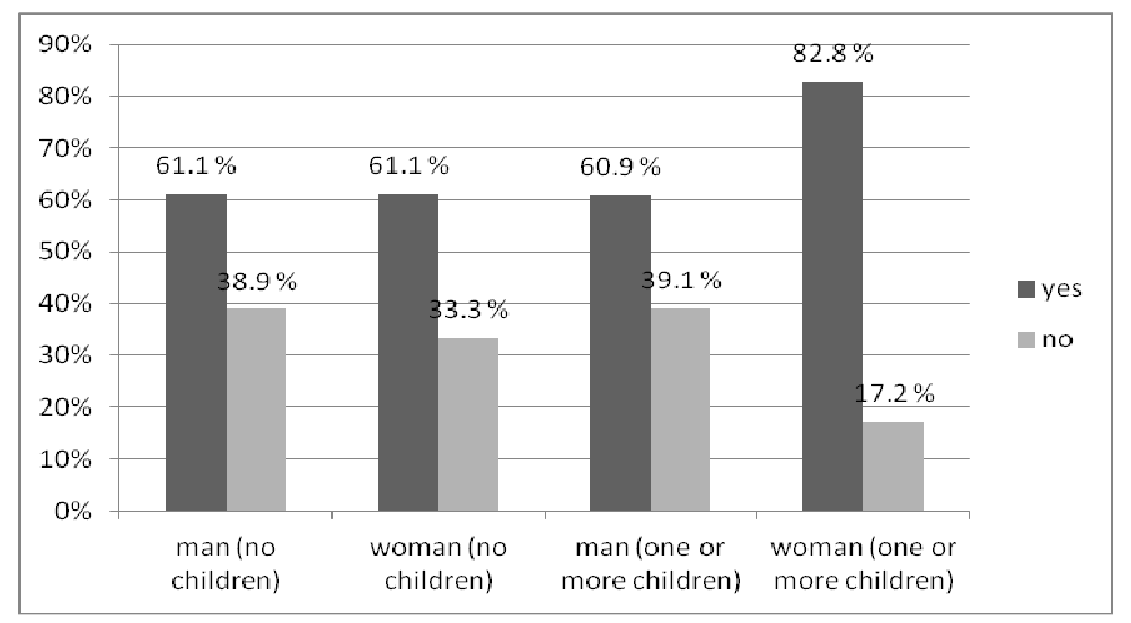

Source: author's own analysis $\quad \mathrm{N}=148$

Figure 3: Differences between the responses of four respondent groups (men and women with and without children) concerning the part-time work option 
The responses concerning the relationship between respondents with and without children depending on their sex indicate that, generally, women more than men believe that a company striving for competitiveness should offer a flexible working hours option. Although the differences between men and women are not statistically significant, the above trend is evident (Fig 4).

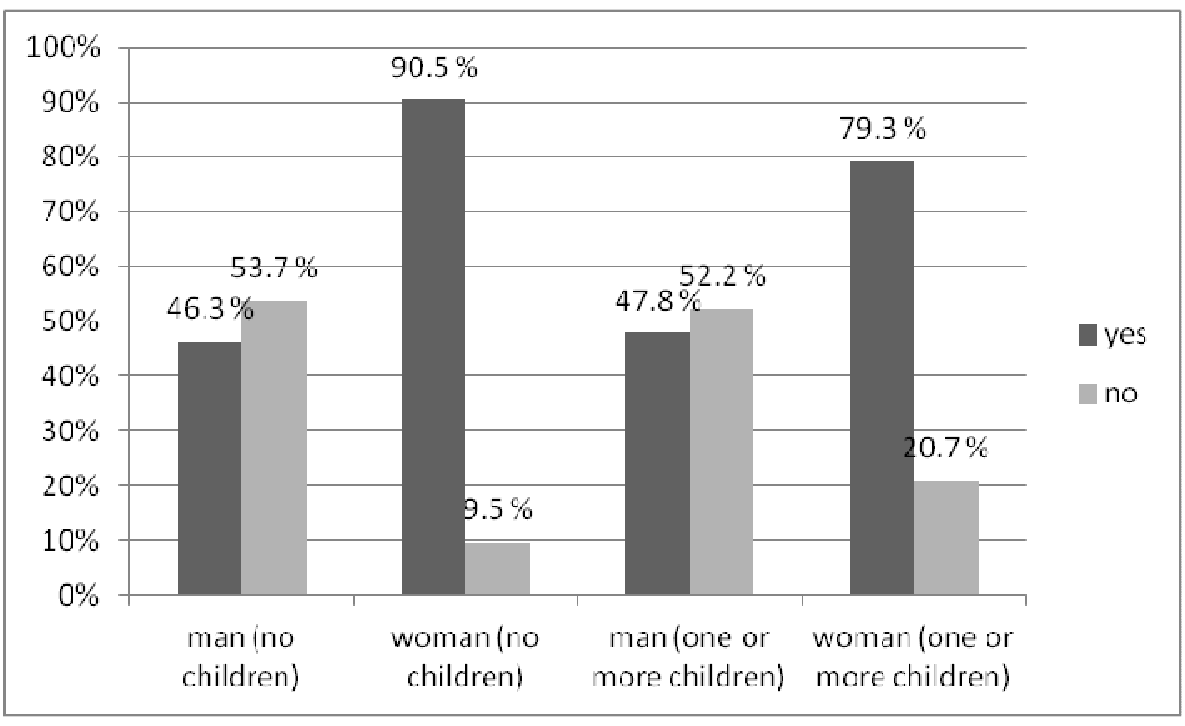

Source: author's own analysis

$\mathrm{N}=\mathbf{1 4 8}$

Figure 4: Differences between the responses of four respondent groups (men and women with and without children) concerning the flexible working hours option

Next we focused on the relationship between childless men and women and those with a child or children and the preferences concerning a company kindergarten. The results indicate that it is again women more often than men who believe that a company striving for competitiveness should offer a company kindergarten (Fig 5). While the differences between men and women were not statistically significant, the two women groups were different at a significance level of $0.01\left(\chi^{2}(\mathrm{df} 1)=6.751, \mathrm{p}=0.009\right)$. Childless women significantly more often (90.5\%) than women with children $(65.5 \%)$ stress the importance of company kindergartens. 


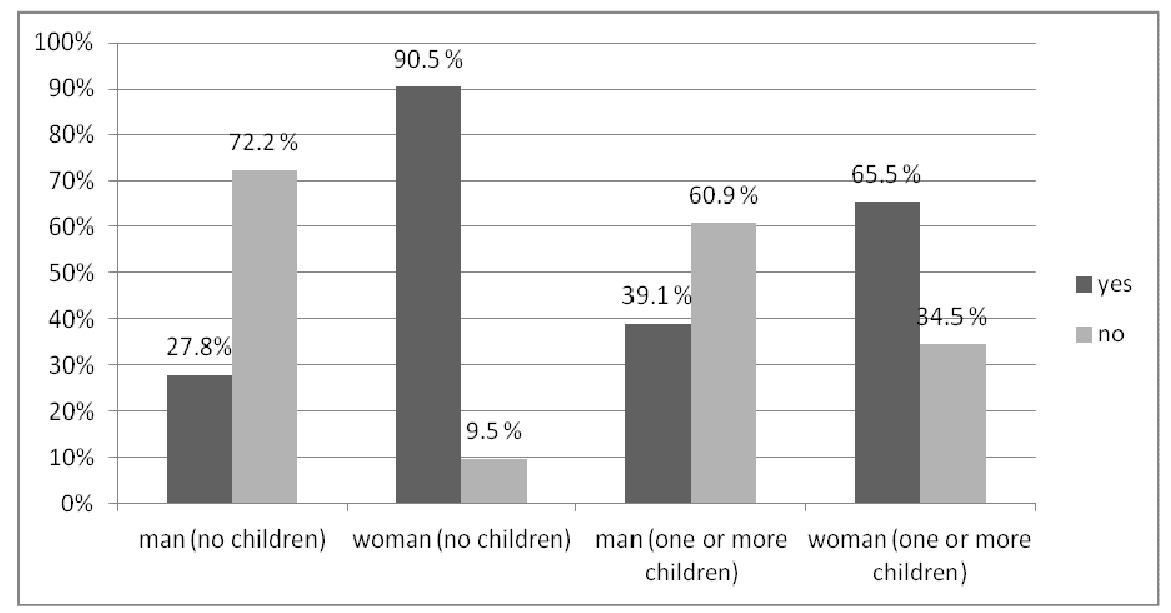

\section{Source: author's own analysis} $\mathrm{N}=148$

Figure 5: Differences between the four respondent groups (men and women with and without children) concerning the company kindergarten option

The work sector of the respondents, too, affects their work life balance preferences. According to Fig 6, respondents working in finance and tax consulting, ICT, and education opt for (in the following order) home office, part-time work, and flexible working hours. On the other hand, home office is regarded as the least interesting option by respondents from manufacturing companies and healthcare. Statistically significant differences were proved between the responses concerning the home office $\left(\chi^{2}\right.$ ( $\left.\left.\mathrm{df} 4\right)=30.671, \mathrm{p}=0.001\right)$, flexible working hours $\left(\chi^{2}(\mathrm{df} 4)=10.221\right.$, $\mathrm{p}=0.037)$, and company kindergarten $\left(\chi^{2}(\mathrm{df}\right.$ 4) $=12,681, p=0,014$ ) options.

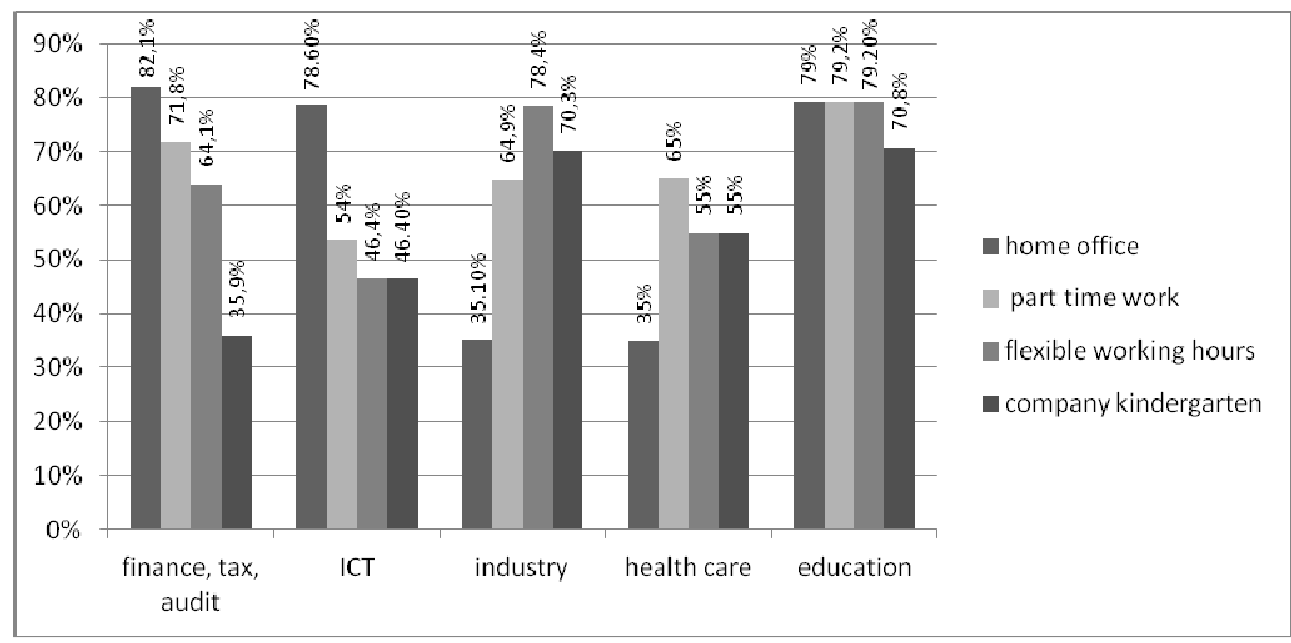

Source: author's own analysis $\mathrm{N}=\mathbf{1 4 8}$

Figure 6: Differences between the work sectors concerning work life balance preferences 
Analysing the responses of men and women divided into five groups by work sectors concerning the home office option, we arrived at remarkable conclusions. Home office is preferred by more than half of the men and women working mostly in finance and tax consulting, information and communication technology, and education (see Fig 7). Generally, women across the sectors more than men regard home office as an option significant for work life balance.

Given sex and professional sector of the respondents, the responses differed at a $1 \%$ level of significance $\left(\chi^{2}(\mathrm{df} 1)=30.671\right.$, $\mathrm{p}=0.001)$, with differences also confirmed between both women $\left(\chi^{2}\right.$ (df 4)=15,599, $\mathrm{p}=0,004)$ by work sector and men $\left(\chi^{2}(\mathrm{df}\right.$ 4) $=17,698, p=0,001)$ by work sector.

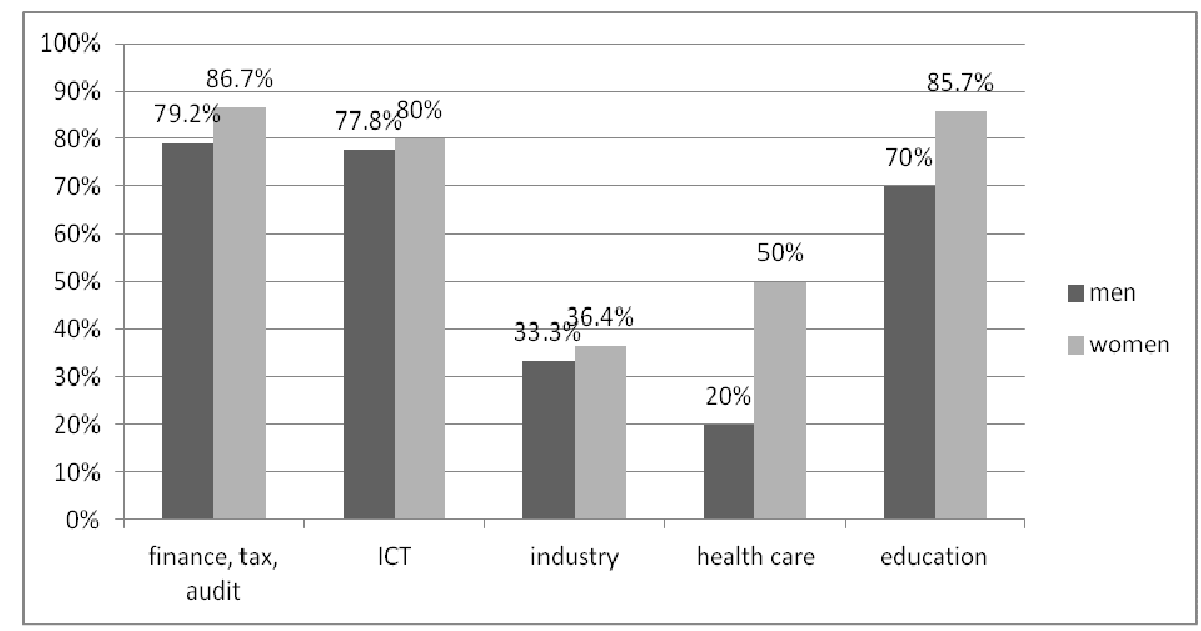

\section{Source: author's own analysis $\quad \mathrm{N}=148$}

Figure 7: Differences between the responses of men and women concerning the home office option given by the work sector. The fig shows the percentages of home office acceptance by the respondents

According to an analysis of the relationships between the sex and work sector of the respondents and their preferences concerning part-time work, this option is mostly preferred by women in healthcare $(90 \%)$, next women in education (85.7\%), in finance and tax consulting $(80 \%)$, more than half of the women working in ICT $(60 \%)$ and industrial companies (59.1\%). In our sample, there were more men (73.3\%) than women $(59.1 \%)$ believing that a company striving for competitiveness should offer this option (see Fig 8). 


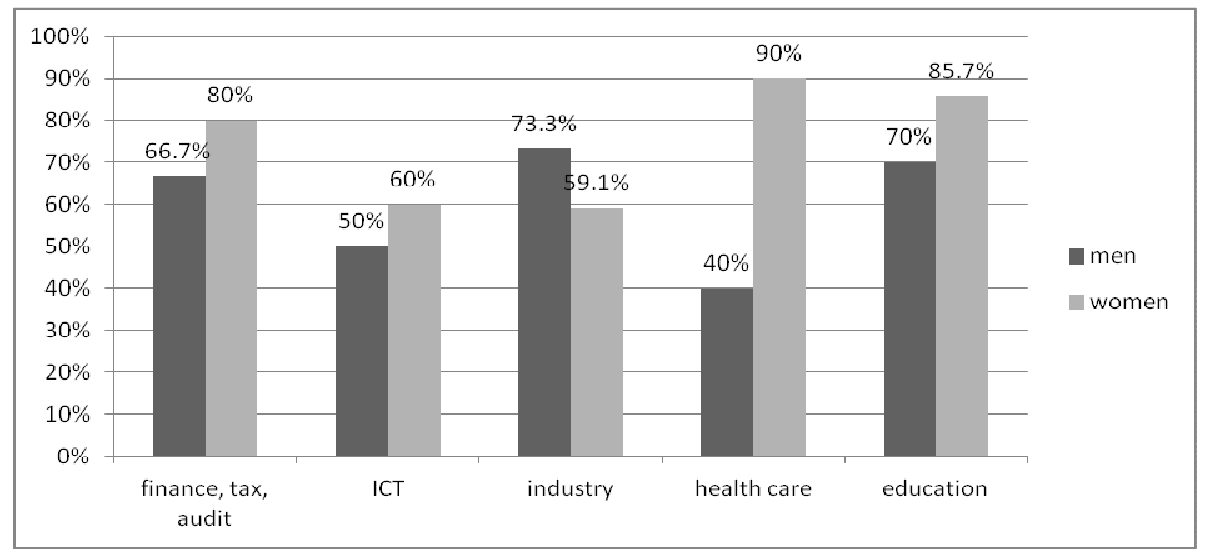

Source: author's own analysis

$\mathrm{N}=148$

Figure 8: Differences between the responses of men and women concerning the parttime work option given by the work sector. The fig shows the percentages of respondents accepting the part-time work option.

More women than men across all sectors would advise the management a company striving for competitiveness to offer a flexible working hours option (see Fig 9). Most women were from industry $(90.9 \%)$

and education (92.9\%). The responses differed at a significance level of five percent $\left(\chi^{2}(\mathrm{df} 4)=10.221, \mathrm{p}=0.037\right)$.

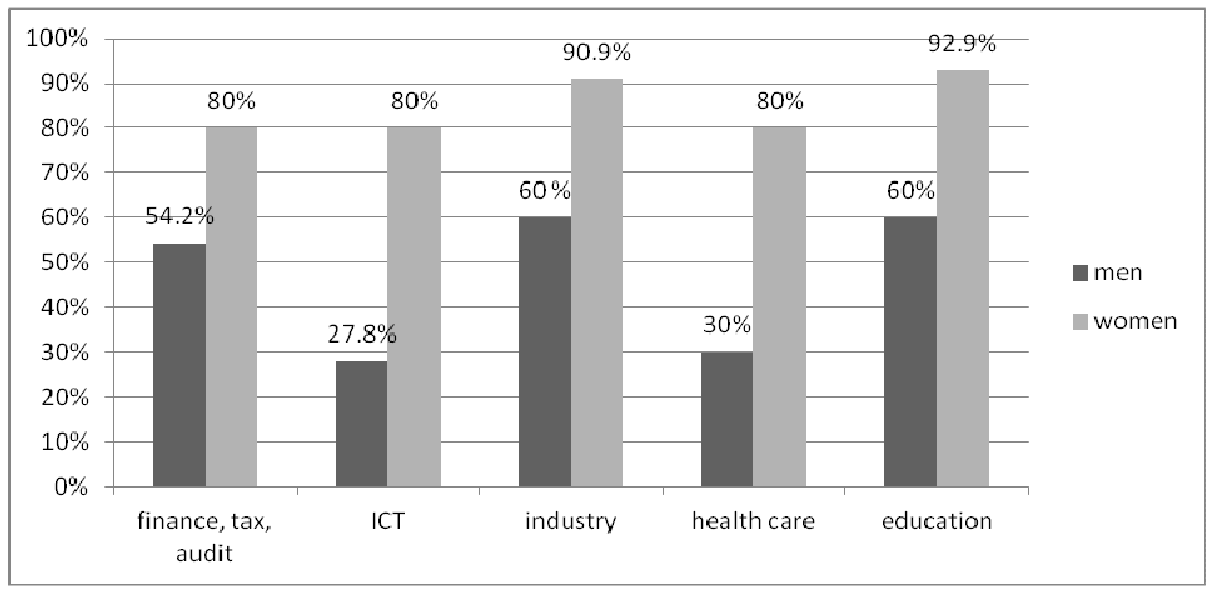

Source: author's own analysis $\mathrm{N}=148$

Figure 9: Differences between the responses concerning the flexible working hours of men and women given by the work sector. The fig shows the percentages of respondents accepting the flexible working hours option. 
Also, concerning the company kindergarten option, there are more women than men in all sectors that believe that this option is important (see Fig 10). The respondents' answers in women differed at a significance level of one percent $\left(\chi^{2}(\mathrm{df}\right.$ 4)=13.813, p=0.008) while those in men differed at a significance level of one percent $\left(\chi^{2}(\mathrm{df} 4)=12.481, \mathrm{p}=0.014\right)$.

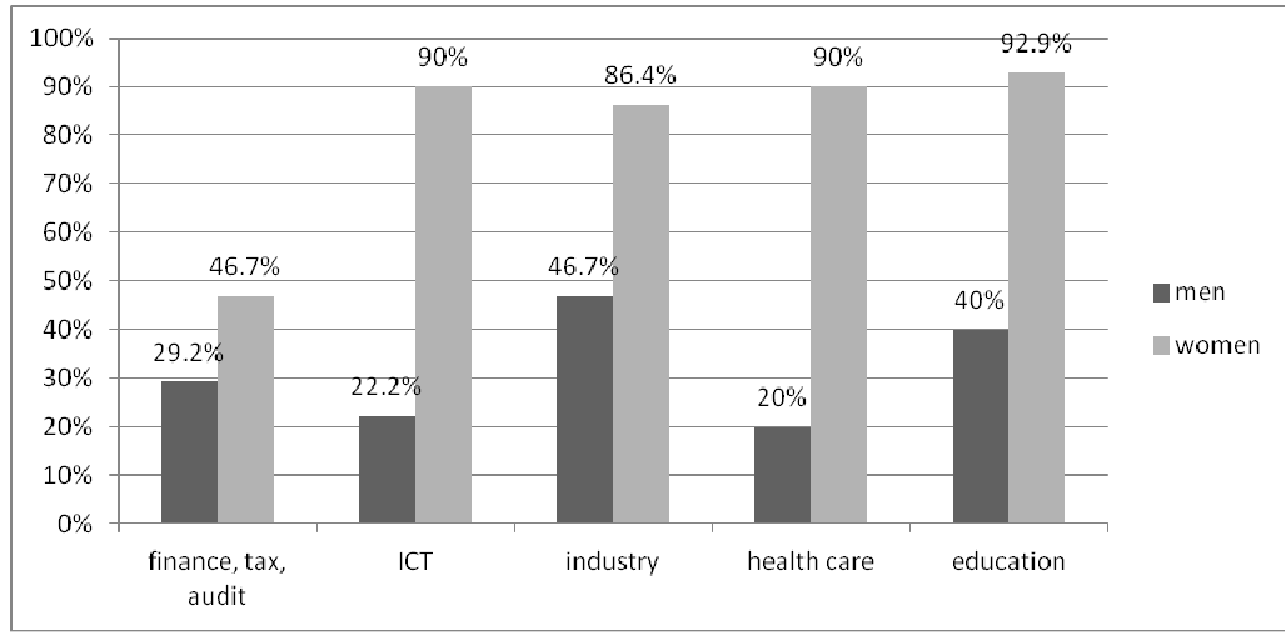

Source: author's own analysis

$\mathrm{N}=148$

Figure 10: Differences between the responses concerning the company kindergarten option of men and women given by their work sectors. The fig shows the percentages of the respondents accepting the company kindergarten option

\section{Summary of results}

All the work life balance options have been accepted by a majority of respondents in the following order: part-time work $66.5 \%$, flexible working hours $64.7 \%$, home office $61.2 \%$, and company kindergarten $54.7 \%$. An analysis of the responses concerning the preferences of men and women confirms unequivocally that women prefer all four options more often than men. Statistically significant are the differences in the case of flexible working hours and company kindergarten. Here, women believe much more that it is offering the flexible working hours and company kindergarten options that can help a company striving for competitiveness win and keep good employees. The results of analyzing the relationship between the respondents without and with children taking into consideration the respondents' sex indicate that women with one or more children more often than other respondent groups (men and childless women) believe that part time work may help the company keep its good employees to improve its competitiveness. The results of analyzing the relationship between the respondents without and with children depending on their sex indicate that women generally more often than men believe that a company striving for competitiveness should offer a flexible working hours option. Although the differences between men and women were not statistically significant, the above trend is apparent. Next, the relationship was analyzed in detail between the childless men and women and those with one or more children with respect to the preferences concerning company kindergartens. The results indicate that it is again women who generally more often than men believe that a company striving for competitiveness should offer a company kindergarten option. The differences between men and women were not statistically significant 
while those between the two women groups were at a significance level of one percent. Childless women significantly more often than those with children stress the significance of the company kindergarten option. The work sector, too, affects the respondents' preferences concerning the work life balance options. Respondents from finance and tax consulting, ICT, and education more often (in the following order) opt for home office, part-time work, and flexible working hours. Respondents from manufacturing companies and healthcare, on the other hand, regard home office as the least desirable option. Analysing the responses to the home office option of men and women divided into five groups by their work sectors, interesting findings have been arrived at. Home office is preferred by more than a half of the men and women working in the finance and tax consulting, ICT, and education sectors. Generally, it is women across all sectors more often than men who regard home office as an option significant for establishing work life balance. Depending on the respondents' sex and work sectors, their responses differed at a significance level of one percent with differences also confirmed between women depending on the work sector and men depending on the work sector. An analysis of the relationships between the respondents' sex and work sector and their preferences concerning the part-time work option has confirmed that this option is the most preferred by women working in healthcare, then women in education and finance and tax consulting, more than a half of the women working in ICT and manufacturing companies. The men in our sample working in industry more often than women said that a company striving for competitiveness should offer this option. Women across all sectors more than men think that a company striving for competitiveness should offer a flexible working hours option. The responses differed at a significance level of five percent. Also, concerning the company kindergarten option, it is women across all sectors more than men who put more emphasis on this option. In women, the responses differed at a significance level of one percent while those in men differed at a significance level of one percent as well.

\section{Discussion and Conclusion}

The work life balance options offered by an employer reflect a concrete situation and the practically implemented offers to employees in a sample of Czech Republic based companies and organisations. The results corroborated the rigidity of options offered by the employer to senior employees (male and female managers), except for the part-time work option offered to a majority of employees (83.8\%), other work life balance options are only offered by a marginal part of companies and organizations (about one fifth of them offer home office and flexible working hours), none of the companies have their own kindergarten with only $11 \%$ percent offering babysitting in exceptional cases.

The results make it clear that, in the current situation, the Czech companies and organizations do not offer sufficient work life balance options. By doing this, the companies run a relatively high risk of losing employees who regard the rigid working conditions as inconvenient

When investigating the work life balance options welcomed by the employees, it was found that a majority of employees would opt for all the options offered in the following order: part-time work $(66.5 \%)$, flexible working hours (64.7\%), home office $(61.2 \%)$, and company kindergarten $54.7 \%$ of the respondents.

Next, differences were confirmed between the option preferences by men and those by women, with women more than men preferring all four options offered, statistically significant were then gender differences concerning flexible working hours and company kindergartens. Thus, despite the men perceiving the achievement of work life balance as more difficult than women as the research has confirmed, they would less than women prefer one of the options. This may be caused by social desirability and social expectation (male imperative), meaning that men are expected to have work and 
professional career appearing at the top of their value system (Rašticová, 2004; Rašticová, Hašková, 2002; Kř́̌žková, 2002, 2003, and others). Part time work, home office, or flexible working hours could then suggest that, to a certain extent, a male manager fails to play the role expected of him by society - the role of a breadwinner. For women, on the other hand, with family and child care still being the top priorities, more work life balance options would bring the opportunity to succeed in both roles, that of a caretaker and that of a professional. In this light, it is quite understandable and predictable that it is women with small children who more than other groups (women without children, with grown up children, and men regardless of their children's age) prefer the work life balance options.

An analysis of the responses by the work sectors revealed that home office is preferred significantly more by ICT and consulting services employees than those of manufacturing companies and healthcare facilities. This result is in conformance with the job descriptions of the sectors. While ICT and consulting specialists can work at home with their main work tool being a computer and highrate access to the Internet, employees of industrial companies and healthcare facilities need a workplace to practice their professions.

When interpreting the results of this research, its limitations must be taken into consideration. The main limitation of the enquiry is the size of the sample, which is not representative and, as such, does not allow for generalizing the research results to the whole population of male and female managers, and senior executives in the Czech companies and organizations. To a certain degree, this limitation was removed by carefully analyzing the demographic data and categories describing the sample structure and indicating the trends in respondent subgroups (by sex, age, management position, employment duration, professional section, etc.). Further research in this area would then deserve more representative samples of male and female managers in Czech-based companies.

Another weakness that needs to be borne in mind when interpreting the research findings is the return rate of the questionnaires. Despite its being relatively high in the present research $(63.8 \%)$, the data have only been collected from a certain part of the respondents. The reactions of the more than one-third of the male and female managers who have not returned their questionnaires can only be speculated on. There may be several reasons for their not doing so such as no time for entering the data, not being interested in the topic, not trusting enquiries in general, not wanting to give their opinions on a particular topic, the request to fill in and return a questionnaire not reaching them having been taken for spam, etc. Whichever the case may be, this is a heterogeneous group that might have affected the enquiry by their responses.

A limitation of the research may also be the method of e-questionnaire enquiry chosen, which, although having a number of advantages, brings some risks, too. Being a quantitative method, questionnaire enquiry results in findings simplified to a certain degree not enabling a more indepth analysis of the problem in its entirety. However, to achieve the research objectives of the research, an equestionnaire has been chosen because the work life balance issues have not yet been given a systematic research approach in the Czech Republic and questionnaires make it possible to collect large data samples quickly. For the subsequent research, a suitable combination of questionnaires and interviews would be desirable complemented by an analysis of company documents enabling a comprehensive analysis and understanding.

In addition to the above suggestions related to the limitations of the research, that is, a larger size of the sample of male and female managers in the Czech based companies and the application of further methods, further research should also include other work life balance options 
such as shortened work week, jobs shared by several employees, and longer holidays outside the season in sectors where this is possible.

Above all, however, further research requires a multidisciplinary approach. In order to acquire a solid understanding of the entire topic and to devise applicable and efficient practical methods, in addition to cooperation with experts in personal management, also one with psychologists, economists, financial analysts, demographers, sociologists, and a number of others is needed, too. It is necessary to give a more detailed study to the relationship between the diversity of personal teams, tolerance to openness and uncertainty, creativity of employees and, next, between the performance of a company and the development of its region and society as a whole taking into account the specifics of the Czech culture and tradition.

\section{References}

1. Arsenault, P. M. 2004. Validating generational differences: A legitimate diversity and leadership issue. Leadership \& Organization Development Journal, 25(2), 124-141.

doi:10.1108/01437730410521813.

2. Bartošová, M. 2008. Životní dráhy prvorodiček po třicítce: proč mít dítě později?

Gender, rovné př́ležitosti, výzkum, roč. 8, č.2/2008. [Online]. [Retrieved 23.8.2011]. Available:

http://www.genderonline.cz/view.php?cisl oclanku=2008012714

3. Bosničová, P. 2010. Rovné příležitosti do firem. 4th ed. Gender Studies, Praha.

4. Cox, T. H. 1993. Cultural Diversity in Organizations. San Francisco, BerrettKoehler.

5. Fischlová, D., Gazdová, M. 2006. Sondáž postojů zaměstnavatelů $k$ uplatnění žen $v$ managementu a zkušeností $s$ nimi (kvalitativní šetření $s$ vybranými reprezentanty zaměstnavatelů ), VÚPSV, Praha.

6. Florida, R. 2004. The Flight of the Creative Class. The New Global Competition for Talent. HarperBusiness, HarperCollins

7. Franková, E. 2009. Ekonomická krize a syndrom vyhoření. Ekonomika a management, $3 / 1$, p.5--12. ISSN 18028470.

8. Frase-Blunt, M. 2003. Moving past 'Mini-Me': building a diverse succession plan means looking beyond issues of race and gender. HR Magazine, 2003. FindArticles.com. [Online]. [Retrieved 24.8.2011]. Available: http://www.shrm.org/pages/login.aspx?re turnUrl=http \%3a\%2f\%2fwww.shrm.org\% 2 fpublications $\% 2$ fhrmagazine $\% 2$ feditorial content $\% 2$ fpages $\% 2$ f1103blunt.aspx

9. Gender studies. Databáze firemních dobrých praxí. 2010. [Online]. [Retrieved 15.4.2011]. Available: http://dobrepraxe.rovneprilezitosti.ecn.cz/

10. Greenberg, J. 2004. Workplace Diversity: Benefits, Challenges, and Solutions. [Online]. [Retrieved 13.3.2011]. Available:

http://www.diversityworking.com/employ erZone/diversityManagement/?id=9.

11. Groeschke, D. 2011. How diverse is diversity measurement really? Some thoughts on diversity measurenment. In Rašicová, M. et al., Diversity is reality. Effective leadership of diverse teams in a global environment. Brno: CERM, pp. 34 43.

12. Harrison, D.A., Klein, K.J. 2007. What's the difference? Diversity Constructs as separation, variety, or disparity in organizations. Academy of Management Review, Vol. 32, No. 4, 1199-1228.
13. Keil, M. et al. 2007. Diversity Management: Vzdělávací manuál. International Society for Diversity Management - idm. s. 55. [Online]. 
[Available 15.10.2010]. Retrieved: www.idm-diversity.org.

14. Králíková, A. 2010. Diverzita: př́íklady hodné následování! [Online]. [Available 15.4.2011]. Retrieved: http://www.rovneprilezitosti.ecn.cz/rovne -prilezitosti-v-praxi detail.shtml?cmd[2786]=x-2786-2270032.

15. Kř́ížková, A. 2011. 'When she earns enough ...' the biographic research approach to gender diversity in the management of organisations. In RAŠTICOVÁ, M. et al. Diversity is reality. Effective leadership of diverse teams in a global environment. Brno: CERM, 68 - 79.

16. Křížková, A. 2002. Životní strategie manažerek: prípadová studie. Praha: Sociologický ústav AV ČR.

17. Kř́žzová, A. 2003. Kariérní vzorce žen v managementu. Strategie žen v rámci genderového režimu organizace. Sociologický časopis 4, 447 - 467.

18. Mahalingam, R., Leu, J. 2005. Culture, essentialism, immigration and representation of Gender. Theory and Psychology, Vol. 15, No 6, 841-862.

19. Commonwealth Secretariat. 2004. The GMS Toolkit An Integrated Resource for Implementing the Gender Management System Series Commonwealth. London: Social Transformation Programmes Division.

20. Putnová, A. 2013. Age management in the Czech Republic viewed through the prism of CSR. In Rašticová et al. Age management. Actual Challenges and Promising Solutions Regarding the Ageing European Population. Brno: CERM. pp. 3760. ISBN 978-80-7204-848-9.

21. PWC, Gender Advisory Council. 2008. The leaking pipeline: Where are our female leaders? 79 women share their stories. [Online]. [Retrieved 20.8.2011]. Available: http://www.pwc.com/en_GX/gx/womenat-pwc/assets/leaking_pipeline.pdf.
22. Rafnsdóttir, G. L., Heijstra, T. M. 2011. Balancing Work-family Life in Academia: The Power of Time. Gender, Work \& Organization. Article first Publisher. [Online]. [Retrieved 4.8.2011]. DOI: 10.1111/j.1468-0432.2011.00571.x.

23. Rašticová, M., Kolářová, I. 2013. Actual challenges of age management in Czech environment. In Rašticová et al. Age management. Actual Challenges and Promising Solutions Regarding the Ageing European Population. Brno: CERM. pp. 1536. ISBN 978-80-7204-848-9.

24. Rašticová, M. 2012. Efektivní přístupy k vedení diverzitních týmů v českých podnicích. Habilitační práce. Brno: Fakulta podnikatelská, Vysoké učení technické $v$ Brně.

25. Rašticová, M. 2011. Česká žena mezi rodinou a profesí. Leadership a management diverzitních týmů z genderové perspektivy. Brno: CERM. 181 p. ISBN: 978-80-7204776- 5 .

26. Rašticová, M. 2007. Kultura, gender a imigrace. Sociálně psychologické hledisko socializace indických imigrantů ve Spojených státech amerických. Gender, rovné př́ležitosti, výzkum, č. 1., roč. 8, p. 2533. ISSN 1213-0028.

27. Riglová, A., Skálová, H. 2008. Ženy imigrantky na trhu práce $v$ České republice bariéry a perspektivy. [Online]. [Retrieved 20.8.2011]. Available: http://zpravodaj.feminismus.cz/clanek.sht $\mathrm{ml}$ ? $\mathrm{x}=2096913 \&$ als $[\mathrm{nm}]=2096951$

28. Ryan, M. K., Haslam, S. A. 2007. The Glass Cliff: exploring the dynamics surrounding the appointment of women to precarious leadership positions. Academy of Management Review, Vol. 32, No. 2, pp. 549-572.

29. Ryan, M. K., Haslam, S. A. 2009. Glass Cliffs Are Not So Easily Scaled: On the Precariousness of Female CEOs'Positions. British Journal of Management, Vol. 20, No.1, pp.13-16. 
30. The Global Online Recruitment Resource. PwC targets women for the top. Posted in News archive. [Online]. [Retrieved 22nd Feb 2011]. Available: http://www.onrec.com/news/newsarchive/pwc-targets-women-for-the-top.
31. Vohlídalová, M. 2007. Vztah pracovního a soukromého života $\mathrm{V}$ perspektivě mezinárodního srovnání. Gender, rovné př́ležitosti, výzkum, roč. 8 , č. 2. [Online]. [Retrieved 8.6.2011]. Available: http://www.genderonline.cz/view.php?cisl oclanku=2008012710. 